\title{
Effects of Leucaena leucocephala (Lamk.) Shoot Tips Plus Young Leaf Extract Containing Mimosine on Reproductive System of Male Rats
}

\author{
Efectos de los Brotes de Leucaena Leucocephala (Lamk.) y del Extracto de Hojas \\ Jóvenes que Contiene Mimosina en el Sistema Reproductivo de Ratas Macho
}

Jaturon Burawat ${ }^{1}$; Nongnut Uabandit ${ }^{1}$; Supatcharee Arun ${ }^{1}$; Somsak Nualkaew ${ }^{2}$ \& Sitthichai Iamsaard ${ }^{1,3,4}$

BURAWAT, J.; UABANDIT, N.; ARUN, S.; NUALKAEW, S. \& IAMSAARD, S. Effects of Leucaena leucocephala (Lamk.) shoot tips plus young leaf extract containing mimosine on reproductive system of male rats. Int. J. Morphol., 36(3):1062-1069, 2018.

SUMMARY: This study aimed to determine the mimosine level and examine the male reproductive toxicity effects of Leucaena leucocephala (LL) shoot tips plus young leaf extract. Mimosine level in LL extract was determined by thin layer chromatography before administration in animals. Male rats were divided into control and LL $(1,500 \mathrm{mg} / \mathrm{KgBW})$ groups $(\mathrm{n}=6)$. After 60 days of experiment, serum sex hormones, sperm quality, and testicular histopathology were assayed and observed. Malondialdehyde (MDA) level and expressions of steroidogenic acute regulatory (StAR) and phosphorylated proteins in testicular lysate were examined by western blotting. Results showed that mimosine levels in LL extract was $17.35 \pm 1.12 \%$ of dry weight. LL significantly decreased FSH \& LH levels, sperm qualities, and seminiferous tubule diameter compared to the control $(\mathrm{p}<0.05)$. Seminiferous tubular atrophies, germ cell sloughing, and degenerations were observed in LL group. In addition, testicular MDA level and StAR protein expression were significantly decreased in LL group. LL extract could increase the expression of a $50 \mathrm{kDa}$ phohorylated protein in testicular lysate. In conclusion, LL extract has mimosine and reproductive toxicity effects on males.

KEY WORDS: Leucaena leucocephala; Shoot tips plus young leaf; Mimosine; Male reproductive system; Rats.

\section{INTRODUCTION}

Currently, many plants have been reviewed to inhibit the spermatogenesis and steroidogenesis (D'Cruz et al., 2010; Daniyal \& Akram, 2015). Although various plants have been documented to have reproductive toxicity in males, the reports about such impairment of commonly edible plants/vegetables are still limited. The Leucaena leucocephala (Lamk.) de Wit (LL) is promoted as a miracle plant because it has many properties such as used for human food, forage, firewood, and high nutritive resources for animal husbandry (Hong et al., 2003; Meena et al., 2013). Some parts of the LL extracts have been documented to possess antioxidant activities (Chanwitheesuk et al., 2005; Maisuthisakul, 2012; Benjakul et al., 2013; Hassan et al., 2013; Burawat et al., 2016). In Latin America (Duke, 1983), the root and bark of LL have been used as antifertility substances. Additionally, young and mature leaves of LL are commonly used as human food and animal feeds in tropical countries including Thailand. This plant is toxic to cattle and poultry animals because it caused the retardation of growth, infertility and death (Anderson $e t$ al., 2001; Clément et al., 2012; Bhatia et al., 2014). Possibly, these toxic effects may result from mimosine action documented as a major toxic content in LL extract (Adeneye, 1991; Chanchay \& Poosaran, 2009). Indeed, mimosine was reported to have inhibitory activities of many cancers, cell divisions, cell proliferations and differentiations (Hughes \& Cook, 1996; Chang et al., 1999; Krude, 1999). Although parts of LL have been wildly consumed in Thailand, its mimosine level and toxic effects on male reproductive system have never been reported. To provide the basic information to caution people about hazardous effects from consecutive consumption and for further development of male alternative contraceptives; therefore, we attempted to investigate the effects of LL shoot tips plus young leaves aqueous extract on reproductive system in male rats.

\footnotetext{
${ }^{1}$ Department of Anatomy, Faculty of Medicine, Khon Kaen University, Khon Kaen, Thailand.

${ }^{2}$ Department of Pharmaceutical Sciences, Faculty of Pharmacy, Mahasarakham University, Mahasarakham, Thailand.

${ }^{3}$ Reproductive Biomedicine Research Group, Khon Kaen University, Khon Kaen, Thailand.

${ }^{4}$ Center for Research and Development of Herbal Health Product, Faculty of Pharmaceutical, Sciences, Thailand.
} 


\section{MATERIAL AND METHOD}

Plant collection and extraction. Leucaena leucocephala (Lamk.) de Wit (LL) cultured Khundong 58 Punmai Farm, Khon Kaen province, Thailand were botanically confirmed by Professor Dr. Pranom Chantaranothai, a plant taxonomist, Department of Biology, Faculty of Science, Khon Kaen University. Then LL samples were kept in the KKU herbarium (no. Jaturon Burawat 02 [KKU]). After 21 days of trimming of the tree branches, the shoot tips and young leaf (24-28 cm in length) of LL were harvested. Samples were aqueous extracted at $100{ }^{\circ} \mathrm{C}$ for $3 \mathrm{~min}$, spun, and dried by using the spray dryer (Nitro A/S-Gladsaxeveg-305-DK2860, Soeborg, Denmark). The extraction yields were approximately $4.74 \%$.

Mimosine content determination using Thin Layer Chromatography (TLC). For standard and LL preparations, mimosine solution $(0.45 \mathrm{mg} / \mathrm{ml}$; Sigma-Aldrich, Lot\# 077K7007V, USA) was diluted with $0.1 \mathrm{~N} \mathrm{HCl}$ and $50 \mathrm{mg}$ LL powder was dissolved in DW. The TLC reagents were carried out following: Analytical ninhydrin reagent was purchased from Ajax Finechem, Australia. Silica Gel 60 F254 Aluminium plates were purchased from Merck, Germany. A CAMAG TLC system (Muttenz, Switzerland) equipped with automatic Linomat 5 Applicator, CAMAG TLC Scanner 3, CAMAG Reproster 3, and CAMAG winCATS software (version 1.4.2) was used. Hydrochloric acid $(\mathrm{HCl})$, butanol, and acetic acid were of analytical grade.

Method validation. TLC method was validated in terms of linearity, limit of detection (LOD), limit of quantification (LOQ), precision, and accuracy. A linearity was first determined by spotting of a series of known-five standard concentration to gain a standard curve. The $\mathrm{R}^{2}$ of mimosine standard curve was 0.99. Second, diluted solutions were spotted on TLC plate to determine a minimum concentration of LL extract that mimosine absorbance can be detected. LOD and LOQ of LL were 0.6 and $2.0 \mathrm{mg} / \mathrm{ml}$, respectively. Third, repeatability (intra-day, $n=9$ ) and reproducibility (inter-day, $n=9$ ) precisions were validated by spotting a concentration mimosine on the stationary phase. Recovery accuracy was investigated to calculate the percentage of relative standard deviation (\%RSD). Percentages of RSD in repeatability and reproducibility were 1.85 and 2.85 , respectively. Finally, the known concentrations of mimosine $(0.27,0.63$, and $0.81 \mathrm{mg} / \mathrm{ml})$ were spotted in different seven lanes along with series of the standard mimosine to evaluate the percentage of recovery (\%recovery). It was found that $\%$ recovery of such concentrations was $101.11,96.16$, and 103.15 , respectively. The accuracy of this method is acceptable $(95 \leq \%$ recovery $\leq 105)$.

\begin{abstract}
Application of validated TLC method to quantify mimosine content in LL. After filtration through Whatmann no.1 paper, LL solutions $(2 \mathrm{mg} / \mathrm{ml})$ were spotted along with standard solution on the chromatoplate. This plate was developed by Butanal: Acetic acid: DW (55: 25: 20; v/v) in a saturated twin trough chamber. Then, the developed plate was dried and sprayed with Ninhydrin. The sprayed plate was captured for the image under UV light, and scanned at $254 \mathrm{~nm}$. The peak areas of the standard and samples were compared to produce the standard curve $(y=4479.7 x+145.63)$. The amount of the mimosine level in LL was calculated in triplicate.
\end{abstract}

Animals and treatment regime. The male Sprague-Dawley rats (6-8 weeks) were purchased from the National Laboratory Animal Center, Thailand. Rats were housed in the Northeast Laboratory Animal Center (temperature $22{ }^{\circ} \mathrm{C} \pm 2{ }^{\circ} \mathrm{C}, 12 \mathrm{~h}$ light/dark cycles), Khon Kaen University, Thailand. Twelve animals were randomly divided into control and LL groups $(\mathrm{n}=6)$. Rats in LL group were orally received with $1500 \mathrm{mg} /$ $\mathrm{kgBW} /$ day of LL for consecutive 60 days while control rats were received with DW. At the end of treatment, all animals were euthanized to collect the blood and male reproductive organs. This experiment was duly approved by the Animal Ethics Committee of KKU, based on the Ethics of Animal Experimentation of the National Research Council of Thailand (Rec. No. AEKKU-NELAC 10/2558).

Sex hormone analysis. Blood samples were collected by cardiac puncture and centrifuged at $13000 \mathrm{rpm}, 4^{\circ} \mathrm{C}$, for 7 $\mathrm{min}$. The plasma was subsequently sent to the Radiology Unit, Srinagarind Hospital, Faculty of Medicine, Khon Kaen University, Thailand to assay the levels of testosterone, follicle stimulating, and luteinizing hormones.

Histopathology. Testis, epididymis plus vas deferens, and seminal vesicles were fixed with $10 \%$ formalin. Gross morphology of these reproductive organs was captured by digital camera (Nikon Coolpix S2600, Japan). Only testis organ was embedded in paraffin, sectioned at $5 \mathrm{~mm}$ thicknesses, and stained with hematoxylin and eosin. Then, testicular sections were observed. In addition, diameter of seminiferous tubules (100 tubules per animal) in control and LL groups was measured in four different axes.

Sperm count assay. Sperm fluid was squeezed form caudal epididymis and dipped into $1 \mathrm{ml}$ of PBS, $37^{\circ} \mathrm{C}, \mathrm{pH}$ 7.4. The fluid was centrifuged at $5000 \mathrm{rpm}, 25^{\circ} \mathrm{C}$, for $2 \mathrm{~min}$. Then, the sperm pellets were re-suspended with $1 \mathrm{ml}$ PBS. The sperm suspension was loaded on Neubauer counting chamber to count sperm in triplicate examinations. 
Sperm head morphology. The sperm was smeared on glass slide and dried in hot air oven at $50^{\circ} \mathrm{C}$ overnight. Then, the dried sperms were fixed with methyl alcohol and stained with haematoxylin and eosin to distinguish normal and abnormal sperm heads. The percentage of abnormal sperm heads was calculated as described by Arun et al. (2016) and Sakr et al. (2014).

Sperm acrosome status. Sperms were fixed in $4 \%$ paraformaldehyde solution and were smeared on gelatincoated slide (Unifrost Microscope Slide, Azer Scientific). The smears were stained with $0.22 \%$ Coomassie blue G250 following mounting with glycerol solution. For sperm acrosome classification, sperm with Coomassie blue staining on acrosome cap was classified as acrosome intact sperm. Sperm without cap blue staining was acrosome reacted sperm as previous reports (Bendahmane et al., 2002; Sukhorum \& Iamsaard, 2017). To quantify the percentage of acrosome reacted sperm, total 200 sperms in each animal were counted.

Testicular malondialdehyde (MDA) assay. Testis was homogenized with RIPA buffer containing protease inhibitor cocktails. Then, the homogenate was centrifuged at 12,000 $\mathrm{rpm}$ at $4^{\circ} \mathrm{C}$ for $10 \mathrm{~min}$. The total protein concentration was measured by using NanoDrop ND-1000 spectrophotometer at absorbance $280 \mathrm{~nm}$. The concentration of MDA was measured by thiobarbituric acid reactive substance assay as described previously (Luangaram et al., 2007).

Western blot analysis. Testicular lysate $(80 \mathrm{mg})$ of both groups was separated on $10 \%$ SDS-PAGE. The proteins were transferred onto nitrocellulose membrane and nonspecific blocked with $5 \%$ skim milk in $0.1 \%$ PBST. Then, the membranes were incubated with StAR antibody (Santa Cruz Biotechnology Inc., USA), b-actin antibody (Santa Cruz Biotechnology Inc., USA), or anti-phosphotyrosine antibody (Millipore Co., USA) at $4{ }^{\circ} \mathrm{C}$ overnight. The membranes were incubated with goat anti-rabbit $\operatorname{IgG}$ secondary antibody (conjugated with horseradish peroxidase [HRP]) for StAR antibody or goat anti-mouse secondary antibody (conjugated with HRP) for b-actin and phosphotyrosine antibodies. The antigen-antibody complex was detected by using enhanced chemiluminescence substrate under gel doct 4 (Image Quant 400, GH Healthcare, USA). The ImageJ program (Version 1.49p) was used to measure the intensity of such proteins.

Statistical analysis. Data were represented as mean \pm standard deviation (SD) and analyzed by using one-way analysis of variance followed by a t-test for multiple comparisons using SPSS Statistics 17.0 software. A value of $p<0.05$ was used to be considered as significant difference.

\section{RESULTS}

Level of mimosine content. A spot of standard mimosine corresponds to that of the first spot of LL (Figs. 1A and 1B). In addition, the mimosine was confirmed from the chromatogram after derivatization with Ninhydrin reagent (Fig. 1B). The purity and chemical structure of standard mimosine were confirmed by Proton Nuclear Magnetic Resonance Spectroscopy (1H-NMR) (Fig. 2). The NMR spectrum of standard mimosine emerges five peaks of 7.607, 6.527, 4.461, 4.407, and 4.099 ppm, respectively (Fig. 2). These proton peaks were further used to predict by Dr. Sirinan Kulchat, a Dynamic Combinatorial Chemist and showed that its chemical structure is of mimosine (Fig. 2). After quantification, mimosine content level in LL extract was $17.35 \pm 1.12 \%$.

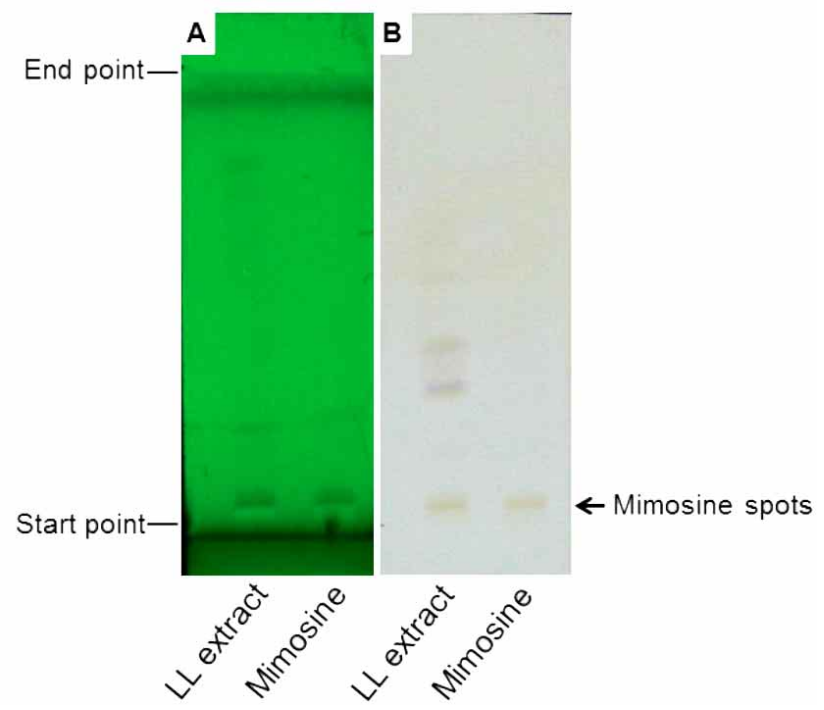

Fig. 1. The thin layer chromatogram of LL and standard mimosine under UV254 nm (A) and visible light sprayed (B) with Ninhydrin reagent.

Effect of the LL extract on sex hormone levels. The levels of testosterone and FSH in LL group were significantly decreased $(p<0.05)$ compared to the control (Table I). However, no significant alteration of LH level was found between groups.

Gross morphology of reproductive organs. The shape and size of testis (Fig. 3A), epididymis plus vas deferens (Fig. 3B), and seminal vesicles (Fig. 3C) in control and LL groups were not obviously different (Fig. 3).

Body and reproductive organ weights. No significant differences in body and reproductive organ weights of LL group compared to control group (Table II). 


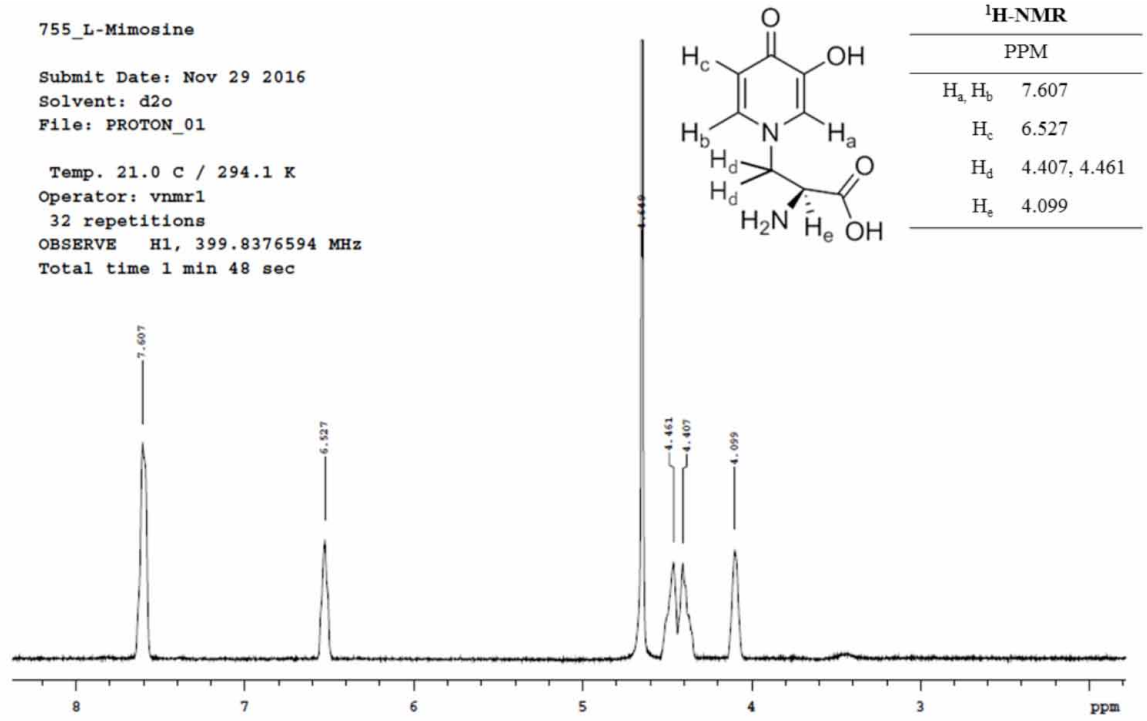

Fig. 2. Proton Nuclear Magnetic Resonance spectrum (1H NMR) of standard mimosine used in present study

Table I. The levels of sex hormones of male rats after treatment for 60 days.

\begin{tabular}{lcc}
\hline Sex hormone levels $(\mathrm{ng} / \mathrm{ml})$ & Control & LL \\
\hline Testosterone hormone & $0.94 \pm 0.07$ & $0.08 \pm 0.05^{*}$ \\
Follicle stimulating hormone & $0.37 \pm 0.16$ & $0.07 \pm 0.02^{*}$ \\
Luteinizing hormone & $0.25 \pm 0.01$ & $0.21 \pm 0.04$ \\
\hline
\end{tabular}

* Significant differences $(\mathrm{p}<0.05)$ as compared with control group.

Testicular histopathology. LL-treated rats showed some histopathologies in seminiferous tubules (Figs. 4B-E) compared to the control (Fig. 4A). Most atrophic seminiferous tubules with large interstitial spaces were seen in LL-treated testis (Fig. 4B and 4C). In addition, Figure 4D represents sloughing of germ cells into lumen of some seminiferous tubules in LL group. Moreover, slight germ cell degeneration (Fig. 4E) was observed in some tubules of LL rats.

Effect of LL on sperm qualities and diameter of seminiferous tubules. Sperm head morphologies were classified into 3 types including normal sperm head with hook (Fig. 5A), abnormal sperm heads without hook (Fig. $5 \mathrm{~B}$ ), and pinhead sperm (Fig. 5C). The percentage of abnormal sperm heads was significantly increased $(\mathrm{p}<0.05)$ compared with control (Table III). Additionally, the percentage of acrosome reacted sperms in treated group was significantly increased (Table III). Moreover, sperm concentration and diameter of seminiferous tubules in LLtreated rats were significantly decreased $(\mathrm{p}<0.05)$ compared to control (Table III).

The malondialdehyde (MDA) level. The MDA level was significantly increased $(\mathrm{p}<0.05)$ in rats treated with the LL
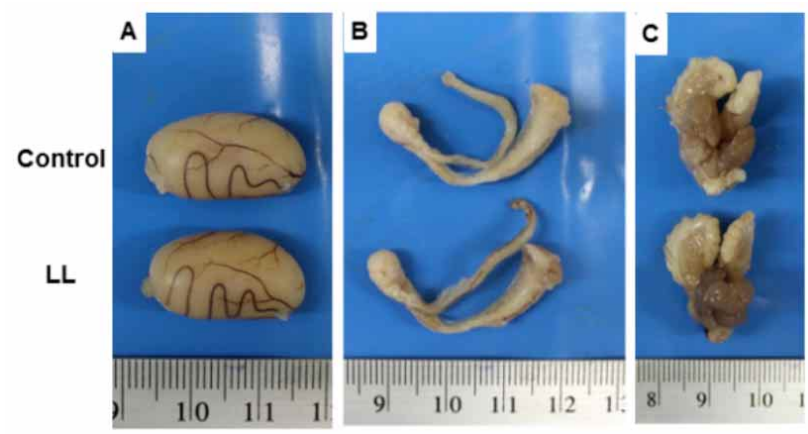

Fig. 3. Gross morphological photographs of testis (A), epididymis plus vas deferens (B), and seminal vesicles (C) of control and LL groups.

extract for 60 consecutive days as compared to that level of control rats (Fig. 6).

Effects of $L L$ on expression of steroidogenic acute regulatory protein. The expression of steroidogenic acute regulatory (StAR) protein in testicular lysate of LL group was decreased as compared to control (Fig. 7A). After intensity quantification using b-actin as internal control, StAR protein of LL-treated rats was significantly reduced $(\mathrm{p}<0.05)$ as compared to control rats (Fig. 7B).

Effects of LL on expression of tyrosine phosphorylated proteins. The patterns of tyrosine phosphorylated proteins were shown in figure $8 \mathrm{~A}$. It was found that expression of a $50 \mathrm{kDa}$-phosphorylated protein in LL-treated group was higher than that of control (Fig. 8A) as also confirmed by its intensity in the figure $8 \mathrm{~B}$. 
Table II. The body and reproductive organs weights of control and LL groups.

\begin{tabular}{lcc}
\hline Parameters & Control & LL \\
\hline Body weights & & \\
$\quad$ Initial $(g)$ & $379.67 \pm 37.67$ & $385.75 \pm 20.30$ \\
$\quad$ Final $(g)$ & & \\
Testicular weights & $3.78 \pm 0.31$ & $4.03 \pm 0.24$ \\
$\quad$ Absolute $(\mathrm{mg})$ & $0.93 \pm 0.01$ & $1.04 \pm 0.11$ \\
$\quad$ Relative $(g / 100 \mathrm{~g} B W)$ & & \\
Epididymis plus vas deferens weights & $0.73 \pm 0.09$ & $0.72 \pm 0.04$ \\
$\quad$ Absolute $(g)$ & $0.18 \pm 0.01$ & $0.19 \pm 0.01$ \\
$\quad$ Relative $(g / 100 \mathrm{~g} B W)$ & & \\
Seminal vesicles weights & $1.90 \pm 0.12$ & $2.01 \pm 0.10$ \\
$\quad$ Absolute $(g)$ & $0.47 \pm 0.07$ & $0.52 \pm 0.03$ \\
$\quad$ Relative $(g / 100 \mathrm{gBW})$ & & \\
\hline
\end{tabular}

Table III. Sperm qualities and diameter of seminiferous tubules of rats after 60 day treatments

\begin{tabular}{lrr}
\hline Parameters & \multicolumn{1}{c}{ Control } & \multicolumn{1}{c}{ LL } \\
\hline Sperm qualitie s & & \\
Sperm concentration $\left(x 10^{6}\right.$ cells $\left./ \mathrm{ml}\right)$ & $39.58 \pm 6.48$ & $26.88 \pm 5.91^{*}$ \\
Abnormal sperm heads $(\%)$ & $0.38 \pm 0.18$ & $3.69 \pm 1.05^{*}$ \\
Acrosome reacted sperms $(\%)$ & $6.50 \pm 0.70$ & $14.88 \pm 1.40^{*}$ \\
Diameter of seminiferous tubules $(\mu \mathrm{m})$ & $315.71 \pm 5.94$ & $279.09 \pm 6.14 *$ \\
\hline
\end{tabular}

* Significant differences $(\mathrm{p}<0.05)$ as compared with control group
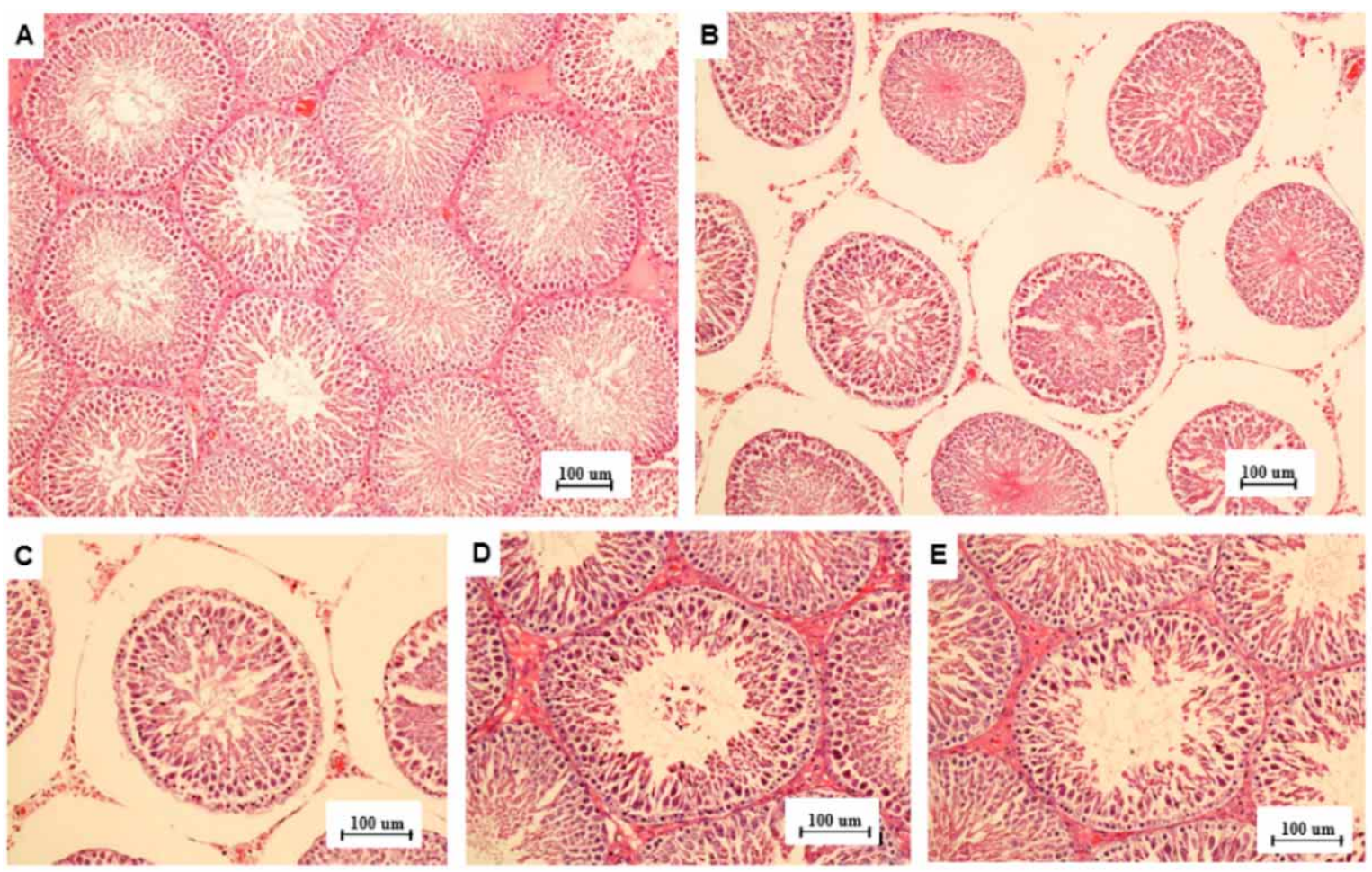

Fig. 4. Testicular histopathology of rats after LL administration for sixty days (A; Control group, B; LL group, C; seminiferous tubular atrophies, D; germ cell sloughing, and E; germ cell degenerations) 
A

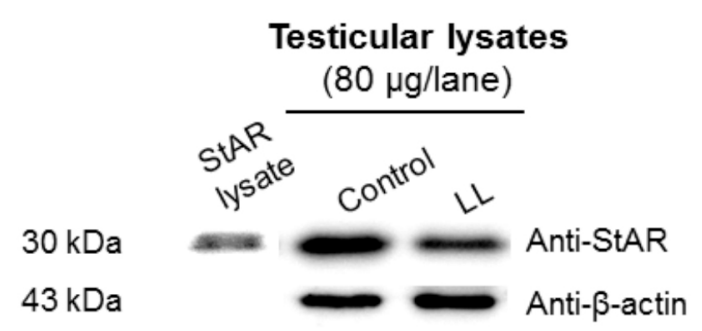

B

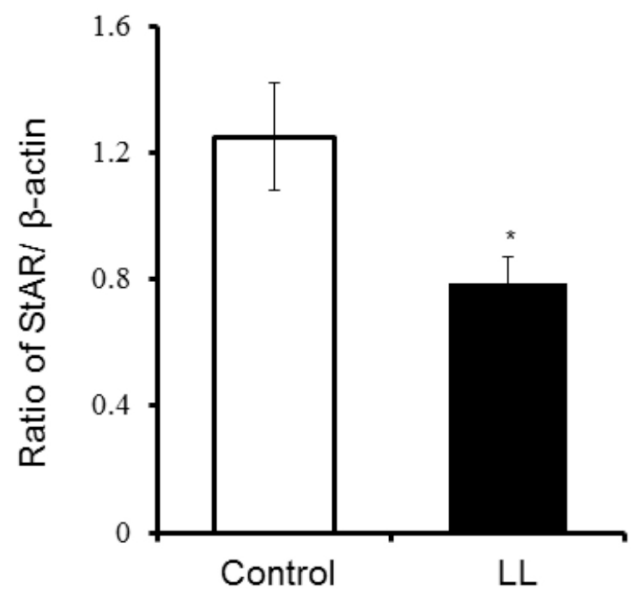

Fig. 7. The immuno-Western blot of steroidogenic acute regulatory (StAR) protein in testicular lysates of rats (A) and intensity ratio of StAR and b-actin (B) [* Significant differences $(\mathrm{p}<0.05)$ as compared with control group].

\section{DISCUSSION}

It is very well known that all parts of LL tree especially leaves and seeds contain mimosine which is proven to have inhibitory activities of many cancers, cell divisions, cell proliferations and differentiations (Wang et al., 1995; Hughes \& Cook; Chang et al.; Krude). The levels of mimosine in LL depend on locations, ages of plant, soil types, seasons, and extraction methods (Ghosh \& Bandyopadhyay, 2007). In colorimetric determination, mimosine level in LL leaves grown in North, Thailand was $4.4 \%$ dry weight (Chanchay \& Poosaran). This study demonstrated level of mimosine in LL shoot tips plus young leaves extract ( $17.35 \%$ dry crude extract) cultured in Northeastern, Thailand, using TLC with method validation for the first time.

This study found that LL extract caused the significant increase of testicular MDA level indicating high lipid peroxidation in testis. Previously, some plants caused testicular damage resulted from increasing of testicular lipid peroxidation (Bajaj \& Gupta, 2012; Kumar Roy et al., 2016;

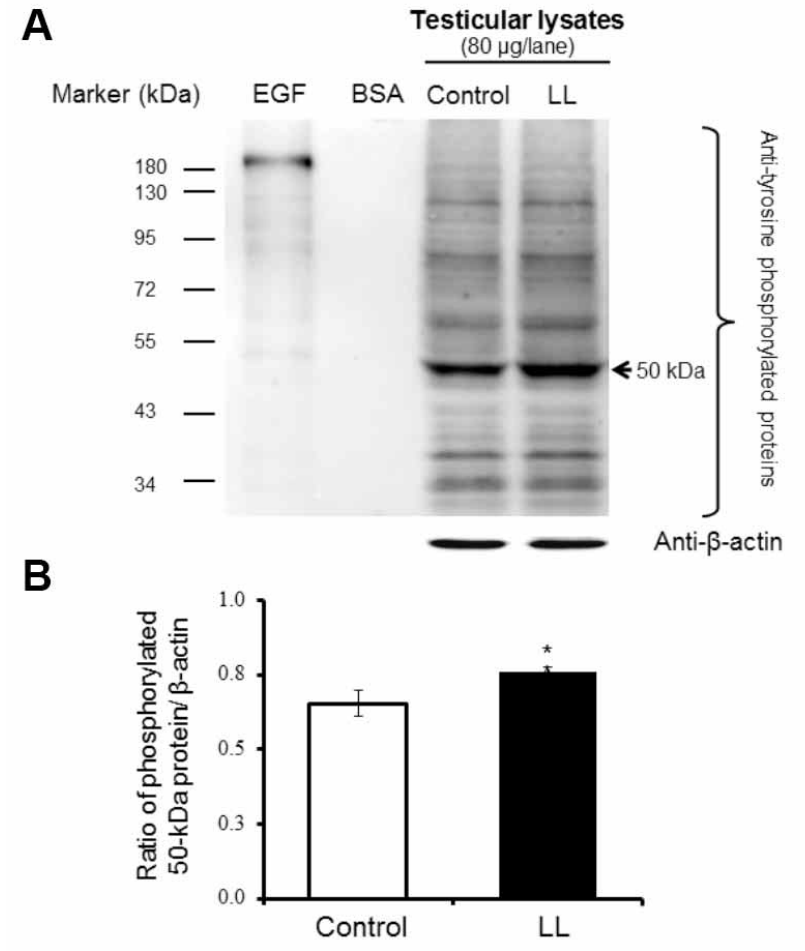

Fig. 8. The immuno-Western blot of tyrosine phosphorylated proteins (A) in testicular lysates of rats (epidermal growth factor [EGF]; positive control and bovine serum albumin [BSA]; negative control) and intensity ratio of $50 \mathrm{kDa}$-phosphorylated protein and b-actin (B) [* Significant differences $(\mathrm{p}<0.05)$ as compared with control group].

Verma \& Singh, 2017). Similar to others, LL can also increase MDA resulting in testicular damages (Fig. 4). The decreased FSH and testosterone hormones in LL group caused spermatogenesis impairment resulting in low-sperm qualities. It was reported that sperm phosphorylated proteins are essential for capacitation and acrosome reaction (Yanagimachi, 1994; Visconti \& Kopf, 1998). The changes of patterns of testicular phosphorylated proteins resulted in alterations of sperm concentration in rats treated with some drugs or substances (Iamsaard et al., 2013, 2014; Arun et $a l$.; Sukhorun \& Iamsaard, 2017). From increasing of a 50 kDa-phosphorylated protein in LL-treated group, we assumed that this protein may be involved in interruption of sperm production. Decreased testosterone could be explained by expression reduction of StAR protein. No alteration of LH and decrease of FSH in LL rats are still unexplained. It is possible that some substances in LL interfered FSH except LH synthesis. Although animals treated with LL were still healthy, their reproductive parameters were impaired. These results suggest that LL extract has direct effect on male 
reproductive system. Degree of testicular damages may depend on mimosine level in LL extract. To caution people in long consumption of LL to avoid the reproductive toxicity, we attempted to calculate the reproductive toxic dose from animal experiment based on $1500 \mathrm{mg} / \mathrm{kgBW}$ in rats. It was found that approximately $426.6 \mathrm{~g} /$ day of LL fresh shoot tips plus young leaves was a toxic dose causing reproductive impairment in men (calculated from $60 \mathrm{kgBW}$ of a man). The reverse effects of LL extract should be further investigation to gain basic knowledge in development of male alternative contraceptives.

\section{ACKNOWLEDGEMENTS}

This study was financially supported by an Invitation Grant, Faculty of Medicine, Khon Kean University, Thailand to Mr. Jaturon Burawat, Nongnut Uabandit, and Dr. Sitthichai Iamsaard (Grant Number IN59313).

BURAWAT, J.; UABANDIT, N.; ARUN, S.; NUALKAEW, S. \& IAMSAARD, S. Efectos de los brotes de Leucaena leucocephala (lamk.) y del extracto de hojas jóvenes que contiene mimosina en el sistema reproductivo de ratas macho. Int. J. Morphol.,36(3):10621069, 2018.

RESUMEN: Este trabajo tuvo como objetivo determinar el nivel de mimosina y examinar los efectos de la toxicidad reproductiva de los brotes de Leucaena leucocephala (LL), más el extracto de hojas jóvenes, en ratas macho. El nivel de mimosina en el extracto de $L L$ se determinó mediante cromatografía en capa fina antes de la administración en animales. Las ratas se dividieron en grupos de control y $L L(1,500 \mathrm{mg} / \mathrm{kgBW})(\mathrm{n}=6)$. Después de 60 días, se analizaron y observaron las hormonas sexuales séricas, la calidad de los espermatozoides y la histopatología testicular. A través de Western Blot se examinaron el nivel de malondialdehído (MDA), las expresiones de reguladores agudos esteroidogénicos (StAR) y las proteínas fosforiladas en el lisado testicular . Los resultados mostraron que los niveles de mimosina en el extracto de $L L$ fueron $17.35 \pm 1.12 \%$ del peso seco. $L L$ disminuyó significativamente los niveles de FSH y LH, la calidad de los espermatozoides y el diámetro de los túbulos seminíferos en comparación con el control ( $\mathrm{p}<0,05)$. Se observaron atrofias en los túbulos seminíferos, desprendimiento de células germinales y degeneraciones en el grupo $L L$. Además, el nivel de MDA testicular y la expresión de la proteína StAR se redujeron significativamente en el grupo $L L$. El extracto de $L L$ podría aumentar la expresión de la proteína fosforilada de $50 \mathrm{kDa}$ en el lisado testicular. En conclusión, el extracto de $L L$ tiene mimosina y efectos de toxicidad reproductiva en los hombres.

PALABRAS CLAVE: Leucaena leucocephala; Brotes más hojas jóvenes; Mimosina; Sistema reproductivo masculino; Ratas.

\section{REFERENCES}

Adeneye, J. A. Mimosine content in various fractions of Leucaena leucocephala grown in western Nigeria. Anim. Feed Sci. Technol., 33(34):349-53, 1991.

Anderson, R. C.; Anderson, T. J.; Nisbet, D. J.; Kibbe, A. S.; Elrod, D. \& Wilkinson, G. Drought associated poisoning of cattle in South Texas by the high quality forage legume Leucaena leucocephala. Vet. Hum. Toxicol., 43(2):95-6, 2001.

Arun, S.; Burawat, J.; Sukhorum, W.; Sampannang, A.; Maneenin, C. \& Iamsaard, S. Chronic restraint stress induces sperm acrosome reaction and changes in testicular tyrosine phosphorylated proteins in rats. Int. J. Reprod. Biomed. (Yazd), 14(7):443-52, 2016.

Bajaj, V. K. \& Gupta, R. S. Fertility suppression in male albino rats by administration of methanolic extract of Opuntia dillenii. Andrologia, 44 Suppl. 1:530-7, 2012.

Bendahmane, M.; Zeng, H. T. \& Tulsiani, D. R. Assessment of acrosomal status in rat spermatozoa: studies on carbohydrate and non-carbohydrate agonists. Arch. Biochem. Biophys., 404(1):38-47, 2002.

Benjakul. S.; Kittiphattanabawon, P.; Shahidi, F. \& Maqsood, S. Antioxidant activity and inhibitory effects of lead (Leucaena leucocephala) seed extracts against lipid oxidation in model systems. Food Sci. Technol. Int., 19(4):365-76, 2013.

Bhatia, H.; Manhas, R. K.; Kumar, K. \& Magotra, R. Traditional knowledge on poisonous plants of Udhampur district of Jammu and Kashmir, India. J. Ethnopharmacol., 152(1):207-16, 2014.

Burawat, J.; Uabandit, N.; Sripanidkulchai, B.; Nualkaew, S. \& Iamsaard, S. Antioxidant capacity and acute testicular toxicity of Leucaena leucocephala aqueous shoot tips plus young leaves extracts. Int. J. Morphol., 34(2):514-21, 2016.

Chanchay, N. \& Poosaran, N. The reduction of mimosine and tannin contents in leaves of Leucaena leucocephala. Asian J. Food Agroind., Special Issue:137-44, 2009.

Chang, H. C.; Lee, T. H.; Chuang, L. Y.; Yen, M. H. \& Hung, W. C. Inhibitory effect of mimosine on proliferation of human lung cancer cells is mediated by multiple mechanisms. Cancer Lett., 145(1-2):1-8, 1999.

Chanwitheesuk, A.; Terrawutgulrag, A. \& Rakariyatham, N. Screening of antioxidant activity and antioxidant compounds of some edible plants of Thailand. Food Chem., 92(3):491-7, 2005.

Clément, C.; Witschi, U. \& Kreuzer, M. The potential influence of plantbased feed supplements on sperm quantity and quality in livestock: A review. Anim. Reprod. Sci., 132(1-2):1-10, 2012.

D'Cruz, S. C.; Vaithinathan, S.; Jubendradass, R. \& Mathur, P. P. Effects of plants and plant products on the testis. Asian J. Androl., 12(4):468-79, 2010.

Daniyal, M. \& Akram, M. Antifertility activity of medicinal plants. J. Chin. Med. Assoc., 78(7):382-8, 2015.

Duke, J. A. Handbook of Energy Crops. Lafayette, Purdue University, Center for New Crops \& Plants Products, 1983.

Ghosh, M. K. \& Bandyopadhyay, S. Mimosine toxicity-A problem of Leucaena feeding in ruminants. Asian J. Anim. Vet. Adv., 2:63-73, 2007.

Hassan, R. A.; Tawfik, W. A. \& Abou-Setta, L. M. The flavonoid constitunts of Leucaena leucocephala. Growing in Egypt, and their biological activity. Afr. J. Tradit. Complement. Altern. Med., 11(1):67-72, 2013.

Hong, N. H.; Xuan, T. D.; Eiji, T.; Hiroyuki, T.; Mitsuhiro, M. \& Khanh, T. D. Screening for allelopathic potential of higher plants from Southeast Asia. Crop Prot., 22(6):829-86, 2003.

Hughes, T. A. \& Cook, P. R. Mimosine arrests the cell cycle after cells enter S-phase. Exp. Cell Res., 222(2):275-80, 1996.

Iamsaard, S.; Burawat, J.; Kanla, P.; Arun, S.; Sukhorum, W.; Sripanidkulchai, B.; Uabundit, N.; Wattathorn, J.; Hipkaeo, W.; Fongmoon, D. \& Kondo, H. Antioxidant activity and protective effect of Clitoria ternatea flower extract on testicular damage induced by ketoconazole in rats. J. Zhejiang Univ. Sci. B., 15(6):548-55, 2014. 
BURAWAT, J.; UABANDIT, N.; ARUN, S.; NUALKAEW, S. \& IAMSAARD, S. Effects of Leucaena leucocephala (Lamk.) shoot tips plus young leaf extract containing mimosine on reproductive system of male rats. Int. J. Morphol., 36(3):1062-1069, 2018.

Iamsaard, S.; Prabsattroo, T.; Sukhorum, W.; Muchimapura, S.; Srisaard, P.; Uabundit, N.; Thukhammee, W. \& Wattanathorn, J. Anethum graveolens Linn. (dill) extract enhances the mounting frequency and level of testicular tyrosine protein phosphorylation in rats. J. Zhejiang Univ. Sci. B., 14(3):247-52, 2013.

Krude, T. Mimosine arrests proliferating human cells before onset of DNA replication in a dose-dependent manner. Exp. Cell Res., 247(1):14859, 1999.

Kumar Roy, V.; Marak, T. R. \& Gurusubramanian, G. Alleviating effect of Mallotus roxburghianus in heat-induced testicular dysfunction in Wistar rats. Pharm. Biol., 54(5):905-18, 2016.

Luangaram, S.; Kukongviriyapan, U.; Pakdeechote, P.; Kukongviriyapan, V. \& Pannangpetch, P. Protective effects of quercetin against phenylhydrazine-induced vascular dysfunction and oxidative stress in rats. Food Chem. Toxicol., 45(3):448-55, 2007.

Maisuthisakul, P. Phenolic constituents and antioxidant properties of some Thai plants. In: Rao, V. (Ed.). Phytochemicals. A Global Perspective of Their Role in Nutrition and Health. London, IntechOpen, 2012.

Meena, D. V. N.; Ariharan, V. N. \& Nagendra, P. P. Nutritive value and potential uses of Leucaena leucopephala as biofuel - A mini review. Res. J. Pharm. Biol. Chem. Sci., 4(1):515-521, 2013.

Sakr, S. A.; Zowail, M. E. \& Marzouk, A. M. Effect of saffron (Crocus sativus L.) on sodium valporate induced cytogenetic and testicular alterations in albino rats. Anat. Cell Biol., 47(3):171-9, 2014.

Sukhorum, W. \& Iamsaard, S. Changes in testicular function proteins and sperm acrosome status in rats treated with valproic acid. Reprod. Fertil. Dev., 29(8):1585-92, 2017.

Verma, H. P. \& Singh, S. K. Antifertility efficacy of Coccinia indica in male mice and its possible mechanisms of action on spermatogenesis. Gen. Comp. Endocrinol., 241:89-99, 2017.

Visconti, P. E. \& Kopf, G. S. Regulation of protein phosphorylation during sperm capacitation. Biol. Reprod., 59(1):1-6, 1998.

Wang, Y.; Zhao, J.; Clapper, J.; Martin, L. D.; Du, C.; DeVore, E. R.; Harkins, K.; Dobbs, D. L. \& Benbow, R. M. Mimosine differentially inhibits DNA replication and cell cycle progression in somatic cells compared to embryonic cells of Xenopus laevis. Exp. Cell Res., 217(1):84-91, 1995.

Yanagimachi, R. Fertility of mammalian spermatozoa: its development and relativity. Zygote, 2(4):371-2, 1994.

\section{Corresponding author: \\ Dr. Sitthichai lamsaard \\ Department of Anatomy \\ Faculty of Medicine \\ Khon Kaen University \\ Khon Kaen, 40002 \\ THAILAND}

Email: sittia@kku.ac.th

Received: 17-11-2017

Accepted: 13-03-2018 